\begin{tabular}{c}
\hline \hline Current Topics \\
in Occupational and \\
Environmental Health \\
\hline \hline Juntendo Medical Journal \\
2014. $60(5), 411-419$
\end{tabular}

\title{
International Collaboration Studies in Central Asia
}

\author{
MOMOKO CHIBA*, TAKEHISA MATSUKAWA* \\ * Department of Epidemiology and Environmental Health, Juntendo University Faculty of Medicine, Tokyo, Japan
}

\begin{abstract}
The shrinkage of the Aral Sea has been called the biggest environmental disaster of the $20^{\text {th }}$ century. The Aral Sea came under the administration of Kazakhstan and Uzbekistan after the collapse of the Union of Soviet Socialist Republics in 1991. People living near the Aral Sea complained of health problems. The aims of this study were to evaluate the potential causes of these problems and how they may be remedied. We conducted a large-scale epidemiological study from the beginning of 1999 in Kazakhstan; the case region was near the Aral Sea and the control region was about $500 \mathrm{~km}$ east of the case region. The subjects were 486 randomly selected schoolchildren in each region for a total of 815 children (383 cases and 432 controls were accepted into the study). The study parameters were anthropometric variables, hematological values, respiratory function, and renal function, in addition to a questionnaire on socioeconomic data and food intake. Body mass index was not significantly different between the two regions. The incidence of anemia was high: $62 \%$ in the case region and $39 \%$ in the control region. With regard to renal function, both urinary $\mathrm{N}$-acetyl $-\beta$-D-glucosaminidase and $\beta_{2}$-microglobulin were significantly higher in the case region than in the control region. Evaluating respiratory function, we found that the prevalence rates of a restrictive pattern were $10.6 \%$ and $2.6 \%$ in the case and control regions, respectively. The obstructive pattern had a low incidence and did not differ significantly between the two regions. The subjects consumed minerals and vitamins in larger amounts in summer, except for vitamins A and D, which were taken more in winter. Sodium concentrations, determined in drinking water, blood, urine, and hair samples, in the case region were higher than in the control region. Two years after the initial assessment in the same children, anemia and renal function had improved. We considered that the health problems that directly correlated with the shrinkage of the Aral Sea might be respiratory dysfunction, caused by particulates, which was much increased after the shrinkage of the Aral Sea. We planted special local trees, saxaul, in one village in order to reduce particulates.
\end{abstract}

Key words: Central Asia, the Aral Sea, anemia, renal function, respiratory function

\section{Introduction}

Central Asia is well known as part of the historical trading route, the Silk Road. In modern history these areas were part of the Union of Soviet Socialist Republics (USSR). In 1991, the USSR collapsed and 15 independent countries arose. Five countries out of those 15 are located in Central Asia: the Republic of Kazakhstan, the Kyrgyz Republic, the Republic of Tajikistan, Turkmenistan, and the Republic of Uzbekistan. People living in these five countries have their own local languages and native customs. Islam is the main religion, except in northern Kazakhstan, where the people are mainly ethnic Russian and Christian. Natural common conditions among these 5 countries are considerable expanses of deserts or steppes, precipitation about $1 / 10$ that of Japan and a continental climate.

There is well known slogan in the field of public health "health for all by 2000", Alma Ata Declaration issued in 1978 by WHO and UNICEF. Alma Ata was the capital city when Kazakhstan was independent. Today, the name of Alma Ata is Almaty and the capital has moved to Astana.

Corresponding author: Momoko Chiba

Department of Epidemiology and Environmental Health, Juntendo University Faculty of Medicine

2-1-1 Hongo, Bunkyo-ku,Tokyo 113-8421, Japan

TEL: +81-3-5802-1047 E-mail: mmchiba@juntendo.ac.jp

[Received Oct. 8, 2014] 
Table-1 Data and statistics of 5 Central Asian countries reported by the WHO regional office for Europe in 2014

\begin{tabular}{|c|c|c|c|c|c|}
\hline & Kazakhustan & Kyrgyz & Tajikistan & Turkmenistan & Uzbekistan \\
\hline mid-year population $\times 10^{4}$ & $1679(2012)$ & $546(2012)$ & $798(2012)$ & $516(2012)$ & $2977(2012)$ \\
\hline \%population aged 0-14years & $24(2010)$ & $30(2010)$ & $36(2005)$ & $39(1998)$ & $33(2005)$ \\
\hline \%population aged $65+$ years & $7(2010)$ & $4(2010)$ & $4(2005)$ & $4(1998)$ & $4(2005)$ \\
\hline life expectancy at birth (years) & $69(2010)$ & $70(2010)$ & $74(2005)$ & $66(1998)$ & $71(2005)$ \\
\hline females & 74 & 74 & 76 & 70 & 73 \\
\hline males & 64 & 65 & 71 & 62 & 68 \\
\hline crude death rate per 1000 polulation & $9(2010)$ & $7(2010)$ & $4(2005)$ & 6(1998) & $5(2005)$ \\
\hline live birth per 1000 population & $23(2012)$ & $27(2011)$ & $28(2012)$ & $30(2012)$ & $21(2012)$ \\
\hline infant deaths per 1000 live birth & $16(2010)$ & $22(2010)$ & $14(2005)$ & 33(1998) & $15(2005)$ \\
\hline $\begin{array}{l}\text { estimated infant mortality per } 1000 \text { live } \\
\text { (World Health Report) } 2012\end{array}$ & 17 & 24 & 49 & 45 & 24 \\
\hline hospital beds per 100000 & $701(2012)$ & $476(2012)$ & $489(2011)$ & $398(2012)$ & $439(2010)$ \\
\hline physicians per 100000 & $350(2012)$ & $196(2012)$ & $170(2011)$ & $228(2012)$ & $225(2012)$ \\
\hline incidence of tuberculosis per 100000 & $107(2012)$ & $113(2012)$ & 64(2010) & $64(2010)$ & $50(2012)$ \\
\hline SDR, all causes, all ages, per 100000 & $1270(2010)$ & $1196(2010)$ & $941(2005)$ & $1331(1998)$ & $1149(2005)$ \\
\hline $\begin{array}{l}\text { SDR, diseases of circulatory system, } \\
\text { all ages, per } 100000\end{array}$ & $621(2010)$ & $702(2010)$ & $561(2005)$ & $844(1998)$ & $754(2005)$ \\
\hline $\begin{array}{l}\text { SDR, external causes of injury and } \\
\text { poisoning, all ages, per } 100000\end{array}$ & $116(2010)$ & $87(2010)$ & $33(2005)$ & 63(1998) & 49 (2005) \\
\hline $\begin{array}{l}\text { SDR, malignant neoplasms, } \\
\text { all ages, per } 100000\end{array}$ & $157(2010)$ & $114(2010)$ & $73(2005)$ & $98(1998)$ & $77(2005)$ \\
\hline $\begin{array}{l}\text { total health expenditure as \% of GDP, } \\
\text { WHO estimates }(2012)\end{array}$ & 4 & 7 & 6 & 2 & 6 \\
\hline
\end{tabular}

WHO statistics for the five countries are summarized in Table-1. The data for each of the four countries are relatively similar, regardless of the year. For example, people under 14 years of age constitute $30-39 \%$ of the population, and $4 \%$ of the population is aged 65 years and over. In Kazakhstan these percentages are $24 \%$ and $7 \%$, respectively, which is closer to the population structure of developed countries. Infant deaths per 1000 live births were 14 in Tajikistan, 15 in Uzbekistan, 16 in Kazakhstan, 22 in Kyrgyz, and 33 in Turkmenistan, but the estimated infant mortality per 1000 live births by the World Health Report of 2012 were 49, $24,17,24$, and 45, respectively. Discrepancies are small in Kazakhstan and Kyrgyz, and large in Tajikistan. The UNICEF office in Kazakhstan reported some differences between the official rate and the survey-based rate from 1992 to 2000, as shown in Figure-1. The medical staff of UNICEF Kazakhstan said that local physicians hesitated to provide actual data to the national medical offices, afraid that upper offices would think that used inappropriate treatments, leading to unexpected results.

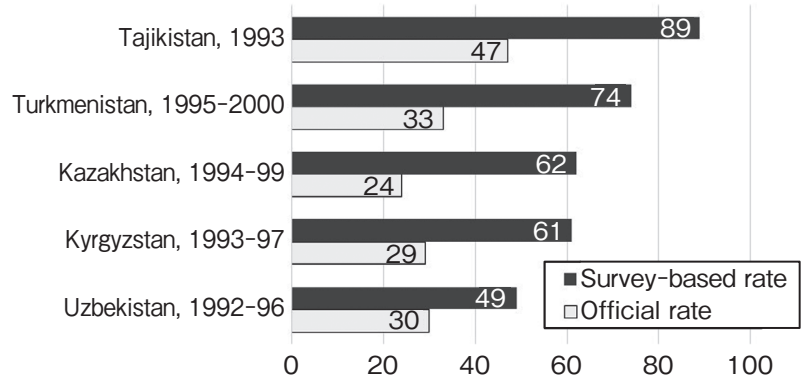

Figure-1 Official and survey-based estimates of infant mortality (infant deaths per 1,000 live births)

The figure with modification is taken from UNICEF (2003), Figure 6-3.

Physicians who collaborated with us said that the period between 1993 and 1994 was especially difficult, because they were not accustomed to a free economy. In the past, vaccines had been provided by Moscow. Everything had been largely dependent on Moscow. The support of the Japan International Cooperation Agency (JICA) was critical in correcting the situation and creating their own system.

Visiting Central Asia is inconvenient. There is only one direct flight between Tokyo and Tashkent 
by Uzbekistan Airways twice a week in summer and once a week in winter. There are flights from Seoul to some cities in Central Asia such as Tashkent, Almaty, Astana, and Bishkek, because more than 1,000,000 Korean tribes live in Central Asian countries after being forcibly moved from the Maritime Province of Siberia by "Stalin's Policy" during the world war. Korean foods such as kimchi, or fermented seaweed, are sold at general markets in both Uzbekistan and Kazakhstan.

\section{The Aral Sea problem}

Central Asian considerable attention has been paid to the shrinkage of the Aral Sea. It is called the biggest environmental disaster of the $20^{\text {th }}$ century. The Aral Sea was the $4^{\text {th }}$ largest lake in the world $\left(66,000 \mathrm{~km}^{2}\right)$, corresponding to about 100 times the size of Lake Biwa and $80 \%$ of the whole of Hokkaido. Two large rivers bring fresh water to the Aral Sea; Syrdarya flows into the northern Aral Sea from the Tian Shan Mountains, and Amudarya flows into the southern Aral Sea from the Pamirs. There is no outlet. Water balance, inflow, evaporation, and precipitation were balanced until the beginning of 1960s. Since then, the sea has become smaller and smaller. The present size is about $1 / 10$ of the original size. In 2000, the Aral Sea was separated into two large parts because of water loss. The two parts are called the main Aral Sea and the north Aral Sea, or the big Aral Sea and the small Aral Sea. The sea shrank because of thoughtless of water usage by USSR. Along with these rivers cottons are produced. Cotton was exported, and then obtain foreign currency. The USSR repeatedly ordered an increase in crop production in the 1950s. Because much water was used in the upper parts of the river for irrigation, a water dam was created, water inflow to the Aral Sea decreased. The Aral Sea was an abundant fishery. However, the salt concentration increased and the fishery was damaged. Simultaneously, the climate changed. When the Aral Sea was large, wind velocity from the North West to the South East weakened, and large particles fell as vapor inclusions. After desiccation, strong winds blew sands and sediments onto southeast villages. According to the official publication of the Ecological Movement of Uzbekistan "sandy and salty storms are raging in this area, spreading million tons of salt, dust, and sand hundreds of kilometers away. Annually around 100 million tons of salty dust enters the atmosphere. From the early 1980s such storms occurred as many as 90 days a year. On the dried parts of the seabed, massive areas of white salty fields appeared, covered with sand that became the new Aralkum Desert with an estimated size of around 5 million hectares. Clouds of salty dust reached as far as 400 $\mathrm{km}$ and more".

After the collapse of the USSR, the Aral Sea became a territory of Kazakhstan and Uzbekistan. The local residents, living on the east and southeast sides of the Aral Sea in both Kazakhstan and Uzbekistan complained of health problems ${ }^{12}{ }^{2)}$. We collaborated with medical and governmental staffs in Kazakhstan and in Uzbekistan. Our study was financially supported by the Toyota Foundation, the Japan Society for the Promotion of Science, JICA and the AEON Environment Foundation.

\section{Collaboration study in Kazakhstan}

In 1994 Prof. Yuichiro Yamashiro, Department of Pediatrics, introduced us to a pediatrician, Prof. Zaira Mazhitova of Kazak National Medical University. She explained that many children living near the Aral Sea suffered from various kinds of diseases and she thought their diseases were related to the shrinkage of the Aral Sea. This was the starting point of our collaboration.

(A) First visit to Kazakhstan in March, 1998

The administrative district of the Aral Sea is in Kazalinsk County in Kyzylorda State. It is about $1,500 \mathrm{~km}$ west from Almaty, the previous capital. The state capital is Kyzylorda City. The air service between Almaty and Kyzylorda City was infrequent and wintertime smog interfered with landing. It is about $600 \mathrm{~km}$ between Kyzylolda City and the central part of Kazalinsk County through the Baikonur Space Center. It took more than 30 hours by train from Almaty to Aralisk, the nearest train station to the Aral Sea. At present transportation system has been much improved.

In our first coming to Kazakhstan we visited following institutions.

(a) Kazakh National Medical University

There are two distinct courses in the medical 


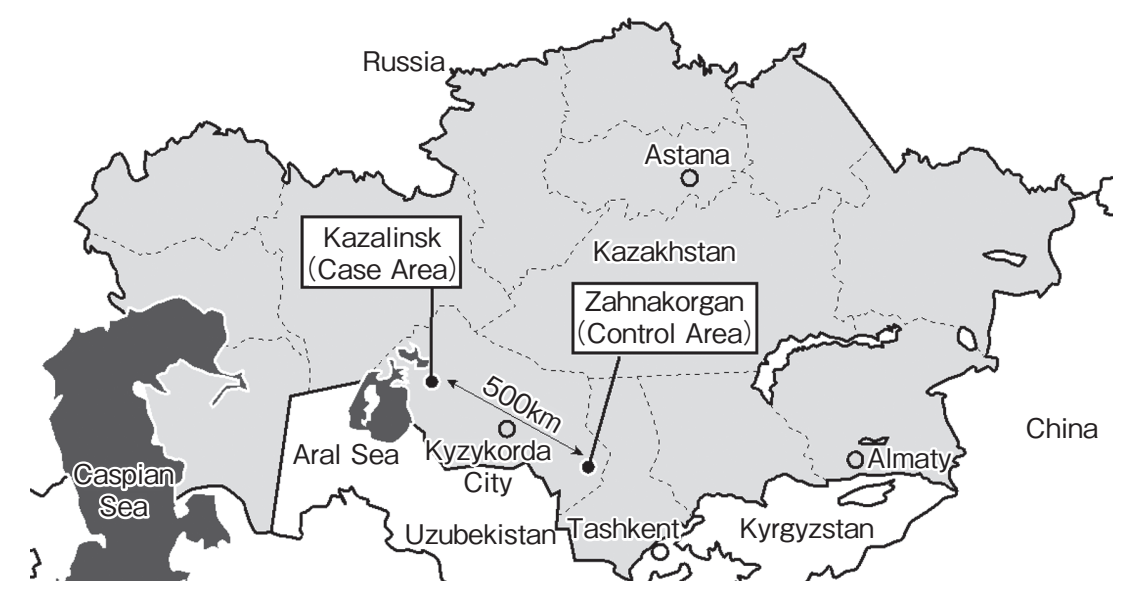

Figure-2 Epidemiological investigation sites (case and control area) in Kazakhstan

school, a general medical course and a pediatrics course. More than $30 \%$ of the population is under 14 years old, and there are not enough medical doctors. Therefore, the USSR started a pediatrics course separately from the general medical course. Medical doctors that graduate from the pediatrics course can treat patients under the age of 15 years. This is the system in all Central Asian countries.

(b) National Children's Rehabilitation Center

This center is in Almaty while the main medical organization for treating environmental diseases. Children with severe diseases near the Aral Sea are brought here for diagnosis and therapy.

(c) Institute of Tuberculosis

Incidence of tuberculosis in Central Asia has been as high as shown in Table-1. This institute has an attached elementary school. About 100 students were studying while receiving therapy.

(d) A local hospital in Kyzylorda State

The local hospital in Jaragash County is about 600 $\mathrm{km}$ east of the Aral Sea. There was a shortage of electricity, no electric light in the inpatient ridge, heating was provided by a pechka, a stove for burning coal, and drinking water was delivered by a small truck. The earth surface around the hospital was covered with white substances that looked like spreading lime. It was identified as salt in our analysis.

(B) Epidemiological Study

(a) Obtaining permission for the epidemiological study and determining the locations

In 1999, we visited the State Ministry of Health and met the director. He brought us to the governor's office where we obtained permission for our study. We then moved to the Aral Sea region where we had discussions with the Health Authority for this region to set the study area and subjects. After visiting three hospitals in Kazalinsk County, and talking with the physicians, we decided to use the Kazalinsk Central Hospital as our base station.

There were 14 villages in Kazalinsk County. Nine villages were selected according to the source of villagers' drinking water: 4 had a deep well, 1 had a shallow well, 1 used river water, and 3 depended on a pipe-delivered water supply besides crossroads. Each village had about 2,000 residents and a health center. As the control region, we selected Zanakolgan County, located about $500 \mathrm{~km}$ east from the case region inside Kyzylorda State (Figure-2).

(b) Small scale pre-study

Two months before the main study, a small scale pre-study was tried for one week at one of the 9 villages to be studied. We learned that questionnaire sheets had to be prepared in the local language and what items to include in the questionnaire. We found that a generator was needed to use clinical instruments and computers because electric power was not supplied during the day.

(c) Training interviewers

Ten local nurses kindly cooperated in our study. To minimize differences between individual interviewers, candidate nurses were trained in advance for one week by a Japanese specialist.

(d) Survey subjects

Personal records of all villagers from birth to present day were kept in the health centers. We obtained permission to release the personal records, 


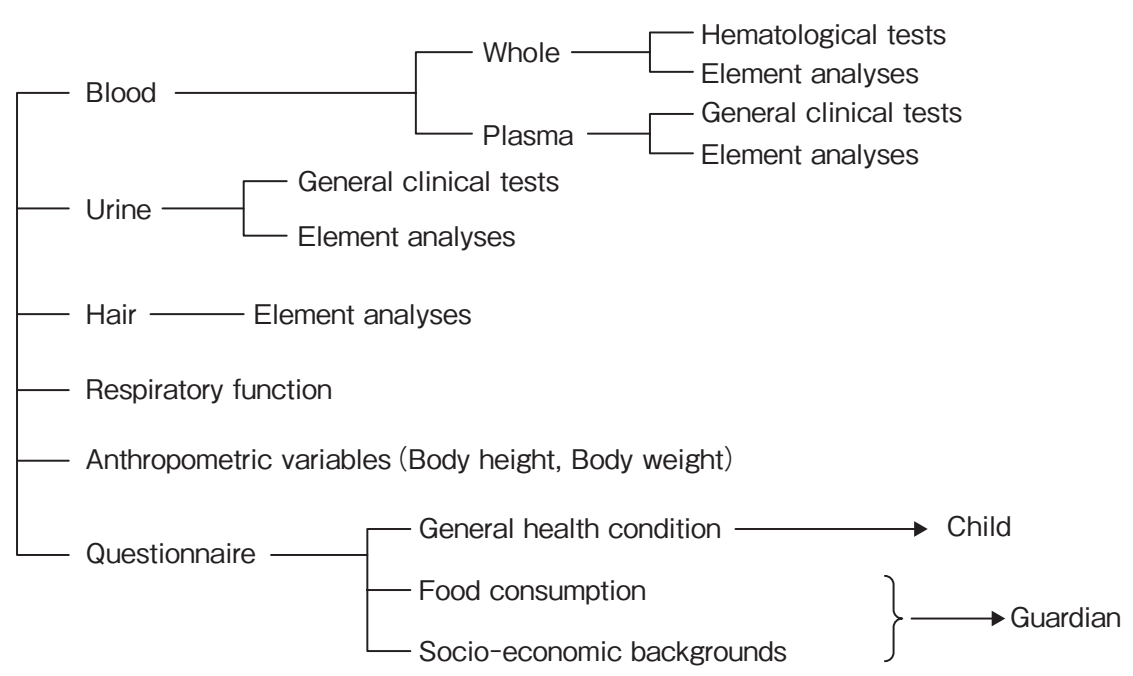

Figure-3 Study items for all subjects

and randomly chose 486 children aged 6-15 years old from the case and control regions. Interviewers visited the children's homes, informed the parents of the purpose of the study, and obtained written consent for participation. Parents and their child came to the health center as a pair with the consent form signed by a parent. Acceptance rates were $79 \%$ in the case region and $89 \%$ in the control region. Subjects were withdrawn if they came with their brother or sister under 18 years of age instead of their parents, or with relatives not living with the subject. To ensure dietary consistency among the participants, only Muslim participants were included in the study.

(e) Study in the case and control regions

The main survey was conducted from July to September, 2000. A follow-up survey was done in July and August in 2002 among the same children in the case region. A winter survey was done in February or March in 2003 and 2004 using the same families. The questionnaire asked about socioeconomic conditions and food consumption. Guardians who came with the subjects answered the questionnaire. The collected variables are shown in Figure-3. The height and weight of children were measured, blood drawn and urine collected. Aliquot of blood samples was immediately applied to a hematology meter and remains were separated to plasma and red blood cells by centrifugation, and then kept cool. Urine samples were checked for $\mathrm{pH}$ and specific gravity, then kept cool. Respiratory function was measured by spirometry. Drinking water was collected. General clinical items and element concentrations were analyzed in Japan.

(f) Results

(i) Anthropometric variables: About 10\% of children in each region had stunting or wasting. Body mass index values $\left(\mathrm{kg} / \mathrm{m}^{2}\right)$ were $16.3 \pm 2.0$ and 16.6. \pm 2.2 (mean $\pm \mathrm{SD}$ ) and the difference was not statistically significant. As for general health status, more than $90 \%$ children in both regions answered as "well" ${ }^{3}$.

(ii) Anemia: $62 \%$ of case and $39 \%$ of control children were estimated as anemia but not severe anemia, according to WHO criteria. Almost all had iron-deficiency anemia ${ }^{3)}$. We considered this a high incidence, which was consistent with food customs. We suggested to the physicians in each village that nutrition education for mothers might correct the anemia. Hematological parameters were improved 2 years following the initial assessment; the average hemoglobin concentrations were over $12 \mathrm{~g} / \mathrm{d} l$ in both groups. We estimated that improvement was due to nutritional conditions ${ }^{4) 5}$.

(iii) Renal function: $N$-acetyl- $\beta-\mathrm{D}$-glucosamidase (NAG) and $\beta_{2}$-microglobulin (BMG) in urine were analyzed. The average values of both NAG and BMG were statistically higher in case than in control children ${ }^{6}$. Calcium concentrations in urine were extremely high in case region ${ }^{7)}$. We discussed this with local physicians and they said the cause of renal dysfunction might be drinking water, but the specific cause in drinking water was unclear. The Minister of Health said the drinking water system in this region had largely altered based on our analytical results. Tap water was 
delivered to individual houses. Unfortunately, they used it only partly, and continuously used the old system to save water charges.

(iv) Food customs: The variety and quality of the food supply was dependent on the season. Therefore, a 24-hour dietary record was tried in the summer and winter in the same families, and micronutrients were calculated using the Kazakh Nutrition Table. Intake amounts of minerals such as iron, magnesium, and calcium were 2 to 5 times, and vitamins such as $\mathrm{B}_{1}, \mathrm{~B}_{2}, \mathrm{~B}_{6}, \mathrm{C}$, carotene, and folic acid were 2 to 6 times higher in summer than in winter. On the other hand vitamins $\mathrm{A}$ and $\mathrm{D}$ were 1.5 to 4 times higher in winter than in summer ${ }^{9)}$. As the ambient temperature in winter is about $-40^{\circ} \mathrm{C}$, there are almost no vegetables and fruits. The people store camel meat for winter. We explained that a balanced daily nutrition is important for health ${ }^{4)}$.

(v) Drinking water: Samples were collected from deep wells, shallow wells, rivers, pipe-deliv- ered water, and commercial water delivered by truck. Various element concentrations were determined. Sodium concentrations were high in all samples, especially in deep-well water. Some of them were close to $1 \%{ }^{10)}$ (Figure-4). Cadmium concentrations were below $4 \mathrm{ng} / \mathrm{m} l$ in all samples. Uranium concentrations in samples collected in the case region were about $20 \mathrm{ng} / \mathrm{m} l$ except in deepwell water, which was close to the detection limit ${ }^{10)}$. As known from the itai-itai disease in Japan, cadmium affects proximal tubules and increases excretion of BMG in urine. Based on this result, cadmium was not the cause of renal dysfunction. Uranium seemed more like the cause but levels were low.

We also tested for general bacteria and Escherichia coli, ${ }^{10)}$. People, mainly children or females, collected water in $40 l$ containers, and brought to their homes, and stored at room temperature. In winter, the colony counts of general bacteria cleared the WHO criteria, $100 / \mathrm{m} l$. In summer,
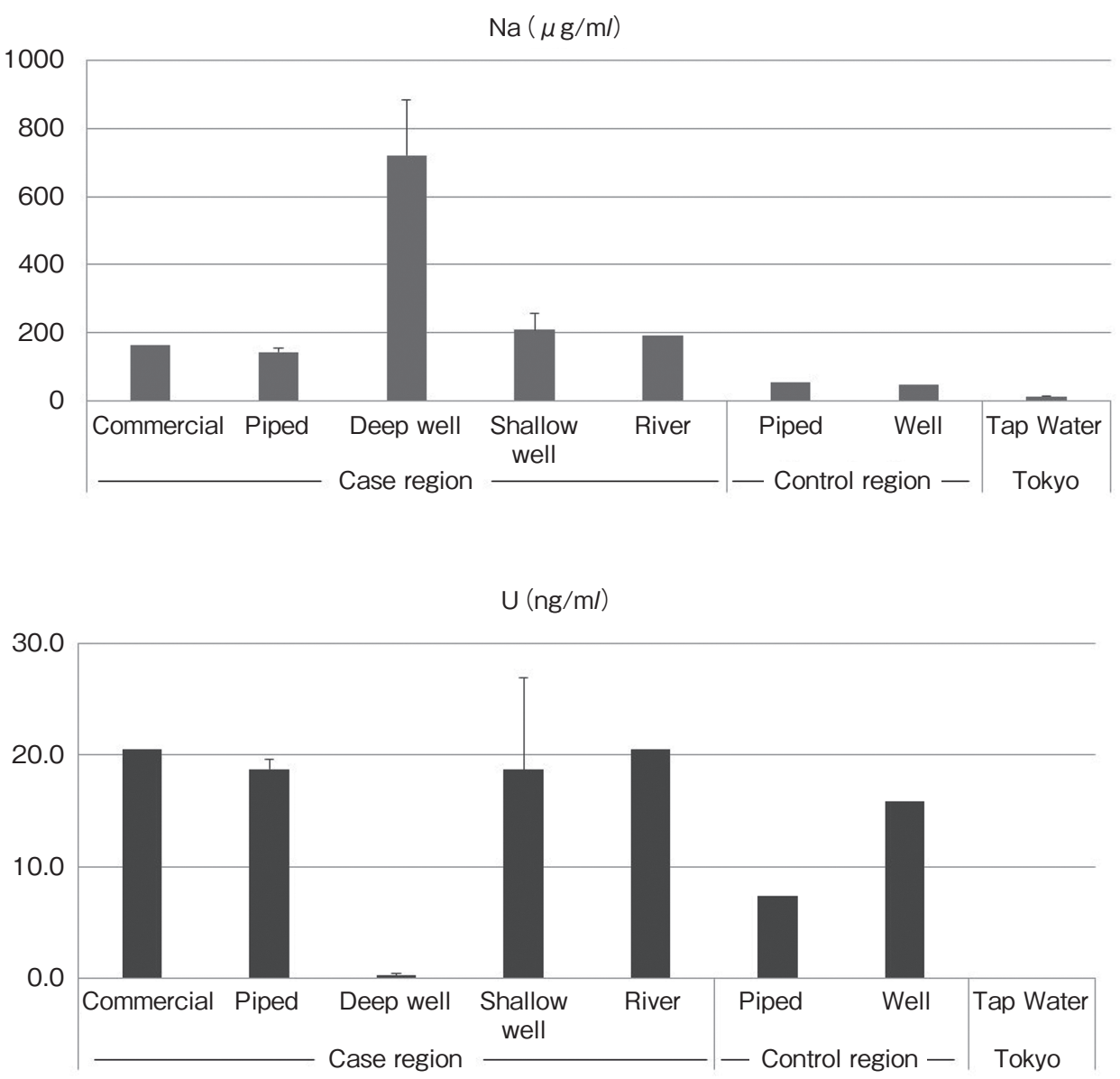

Figure-4 Sodium (Na) and uranium (U) concentrations in drinking water samples 
however, some samples were over the criteria, with the maximum $1,136 / \mathrm{ml}$. E. coli was positive in all samples in winter, but values were small, 1-20 except for one which was $94 / \mathrm{ml}$. In summer they were negative to $1,024 / \mathrm{m} l$. The negative samples were probably chlorinated ${ }^{11)}$.

(vi) Respiratory function: Respiratory function was checked by spirometry. The prevalence of restrictive patter was $10.6 \%$ and $2.6 \%$ in the case and control regions, respectively. Obstructive pattern was of low prevalence and not statistically different between the regions ${ }^{12}$.

(vii) Particle sizes and contaminants of suspended particle matters: High prevalence of restrictive pattern in case region was paid attention ${ }^{12}$. In order to know if its cause was particles themselves or contaminants adhering particles, 10 dust traps were set in both case and control regions for one year. Every month contents of dust traps were collected. Particle sizes were measured by an electron scanning microscope. As the results particle sizes were mainly under $10 \mu \mathrm{m} ; 82$ to $96 \%$ in case regions, 89 to $97 \%$ in control regions, $71 \%$ in Kyzylorda city ${ }^{13)}$. As to agricultural chemicals 20 kinds of organic phosphorus and 20 kinds of organic chlorine chemicals were screened. Small amounts of eldrin and dieldrin which were derivatives of $\mathrm{BHC}$ and DDT, were detected, but they were too low to effect on adverse effects to human bodies ${ }^{13)}$.

(viii) Planting trees for reducing particulates: The cause of respiratory dysfunction was thought to be suspended particulates. After the Aral Sea was desiccated, the wind velocity became stronger and carried dust and sand as mentioned above. The local physician and the village mayor said that the one measure taken to reduce particulates was to plant a row of trees along with villagers' houses. We discussed with a special botanist, Dr. Liliya Dimeyeva, of the Institute of Botany in Kazakhstan. She suggested planting saxaul (Haloxylon aphyllum). This plant survives only in this dry area and its roots grow to $15 \mathrm{~m}$ long. We planned planting 1,000 seedlings of saxaul. We visited an elementary school nearby, and explained the importance of environmental protection and our plan. Students joined in planting trees, and called this place a "friendship garden”.

\section{Collaboration study in Uzbekistan}

The rationale for the collaboration with Uzbekistan was the Aral Sea problem. We visited the Tashkent office of Doctors without Borders (Medecins Sans Frontieres) and discussed the Aral Sea problem. An Uzbek physician, Dr. Dilorom Fayzieva, joined our project. We started to cooperate solving environmental problems in Uzbekistan.

\section{(A) The Aral Sea problem in Uzbekistan}

The south half of the Aral Sea is Uzbekistani territory. Muinak was a waterfront town, but today the shore is far away from Muinak. Access to the Aral Sea is by flying from Tashkent to Nukus, which is frequent services, and about $200 \mathrm{~km}$ to Muinak. Access to the Aral Sea is easier on the Uzbekistan side than on the Kazakhstan side. As the Aral Sea problem is well known globally, many groups of investigators come to this area from foreign countries. No groups have come to the Kazakhstan side except for Japanese groups. Groups from the USA, France, UK, Germany, and the Netherlands, went to the Uzbekistan side only. Nukus is the capital of the autonomous republic of Karakalpakstan inside Uzbekistan. The members of the Nukus Medical Institute have been treating health problems of the local residents including near the Aral Sea. They measured parameters of local children by physical techniques. Recently biochemical measurements were started and found an incidence of anemia in children similar to our results in Kazakhstan.

\section{(B) Ecological Movement (EcoMovement) of Uzbekistan}

Uzbek national assembly is a bicameral system. Lower chamber has 150 seats. In 2008, 15 seats were allotted to the EcoMovement in the lower chamber. Dr. Dilorom Fayzieva was elected as a member. EcoMovement is a political party, and addresses concerns to the environment. EcoMovement of Uzbekistan held several times of the international conferences on the Aral Sea problem in Tashkent and in Tokyo. Recently this party has addressed two environmental problems: environmental pollution in the Sulkhandaria region and the Rogun hydrogen power plant. 
(C) Transnational pollution problems in Surkhandarya State in Uzbekistan

Surkhandarya State is in the southeast of Uzbekistan, bordering the next country, Tajikistan. Northern Surkhandarya State has problems with air, soil, and water contamination of human beings, livestock, plants and agricultural products. Human health problems are dental, skeletal, reproductive, developmental, renal, neurological, endocrinological, and gastrointestinal. EcoMovement pointed to hydrogen fluoride (HF), included exhausted gas and waste, which was discharged from a huge aluminum refining plant since 1975 in Tajikistan. This is a transnational pollution problem. EcoMovement of Uzbekistan held an international workshop "On measures of neutralization of catastrophic impact on the environment and population health of the industrial activity of the Tajic state unitary enterprise" in Tashkent in August, 2013. EcoMovement showed that morbidity in this area was 3 times higher in comparison with other areas. The incidence of respiratory disorder, diseases of the blood or blood forming organs, and disorders of the endocrine system were increasing in every county in this area. Analytical data for fluoride was mentioned. A Tajik participant denied that the pollution source was the plant in Tajikistan because an audit confirmed that the environmental safety system of this plant was in compliance with ISO-14000 and OHSAS-18000.

The day before the workshop many participants inspected the polluted area, northern Surkhandarya, inside Uzbekistan. They recognized the damage there including the mottled teeth of children, animal anomalies, plant growth disorders, and infant anomalies, seen in photos.

The existence of the damage is obvious, and the cause may be estimated, but further investigation is necessary to clarify the real cause. Nobody knows where it comes from. At present, they think contaminants in the air are the cause, which may be correct, but there are other possibilities, including contaminants from water or soil. It is important to elucidate the cause and remove it as soon as possible.

(D) Rogun hydrogen power plant

Another concern of EcoMovement of Uzbekistan is the Rogun hydropower station beside the Vakhsh
River in Tajikistan. This giant hydropower station was planned in 1974 during the USSR period. The reservoir capacity is $13.3 \mathrm{~km}^{3}$. EcoMovement worries about the location: At $335 \mathrm{~m}$ in height, the highest in the world, and in an active seismic zone, with an estimated probability on the Richter scale of 9. Dam construction may trigger a new earthquake in a seismically active zone. If an earthquake occurs and if the embankment collapsed, many villages in not only Uzbekistan and Tajikistan, but also in neighboring countries would be destroyed and there would be many victims. The Vakhsh River flows through many countries including Uzbekistan. Water usage in the upper part might influence cotton production downstream. This year, the Tajik authorities announced that they resumed works on the construction of the Rogun dam without waiting for the opinions from international experts.

\section{Further considerations on the Aral Sea by Kazakh- stan and Uzbekistan}

The Kazakhstan government created a dam at the south end of the north Aral Sea in 2005. The north Aral Sea is entirely in Kazakhstan, but the south half of the main Aral Sea is a territory of Uzbekistan. The river Syldarya still brings fresh water to the north Aral Sea, and therefore, the Kazakhstan government decided to keep the north Aral Sea, and created a dam to save water. The salt concentration was then lowered, and the fishery has gradually recovered.

However, the river Amdarya disappeared some ten $\mathrm{km}$ before the Aral Sea. From the dried up bottom of the southern part of the Aral Sea natural gas has been obtained. Therefore, the Uzbekistan government has a conundrum: if water returns, gas might be missed. Another solution might be under discussion. Anyway, after dam construction by Kazakhstan, the Uzbekistan side worried that desiccation would be accelerated. The International Organization and aid of Germany extensively conducted saxaul plantation.

\section{Key points of international collaboration}

When field work is being planned in foreign countries, important points from our experience are the following; a) Pre-study - a pre-study provides much information such as determining which language is best to use in interviews when pre- 
paring the questionnaire. Additionally it provides a communication tool to use with local physicians and subjects, providing information on their lifestyle. We learned that we should bring a generator and types of outlets for power sources from Japan or from large cities inside the country. b) Interpreters - we have to rely on interpreters and avoid mistranslation. Excellent interpreters are necessary, who hopefully understand medical terms. c) Avoiding problems at emigration and immigration counters at airports - when certain equipments or chemicals are brought to foreign countries, taxes are sometimes requested. One solution is to explain the problem to the embassy staff when the visa is requested. When biological samples are brought back to Japan, we must follow the foreign country's rules. Some countries do not permit export of blood samples. In the case of soil, we have to inform the quarantine station in Japan before departure, and follow the rules. d) Dealing with the results Study results are shown first to the head of the co-operative members, and then discussed with the main members. Their suggestions are important to consider in the results because they well know the backgrounds of the subjects. We expect our study results improve their lives. We hope the local staffs will use our methods and continue the survey to maintain a clean environment by themselves.

\section{Conclusion}

There were many problems in the Central Asian countries during the years just after independence. Since then, they have been developing continuously and quickly. The power supply in the local area in Kazakhstan became available all day since 2006 . Turkmenistan will hold the Asian Games in 2018. Gross domestic product is gradually but certainly increasing in each country. Natural resources such as gas, oil, and minerals are rich in this area. We, the Japanese, should not forget that pollution could trigger diseases. The Japanese government prioritized economic goals and paid no attention to environmental pollution. We learned much from such cases. In order to clean up Minamata Bay area, sediments of 1.5 million $\mathrm{m}^{3}$ contaminated with more than 25 ppm mercury were removed and it took 23 years, from 1973 to 1997. Many people are still suffering and the legal process continues. Once the environment is contaminated much time and cost are expended to solve the problem. Environmental protection is important.

\section{References}

1) Chiba M: Ecological diseases of children living in Kazakhstan. Japanese Journal of Clinical Ecology, 1998; 7: 95-99. (in Japanese)

2) Chiba M: Health disorder happened around the Aral Sea, ecological diseases. Investigation Reports of the Japan Research Association on Kazakhstan, 2000; 8: 8396. (in Japanese)

3) Hashizume M, Kunii O, Sasaki S, et al: Anemia and iron deficiency among school children in the Aral Sea region, Kazakhstan. J Tropical Pediatrics, 2003; 49: 172-177.

4) Hashizume M, Shimoda T, Sasaki S, et al: Anaemia in relation to low bioavailability of dietary iron among school-aged children in the Aral Sea region, Kazakhstan. International Journal of Food Sciences \& Nutrition, 2004; 55: $37-43$.

5) Hashizume M, Chiba M, Shinohara A, et al: Anaemia, iron deficiency and vitamin A status among school children in rural Kazakhstan. Public Health Nutrition, 2005; 86: 564-571.

6) Kaneko K, Chiba M, Hashizume M, et al: Renal tubular dysfunction in children living in the Aral Sea Region. Achieves of Disease in Childhood, 2003; 88: 966-968.

7) Kaneko K, Chiba M, Hashizume M, et al: Extremely high prevalence of hypercalciuria in children living in the Aral Sea region. Acta Paediatr, 2002; 91: 1116-1120.

8) Kaneko K, Yamashiro Y, Chiba M: Another factor influencing the urinary calcium excretion. Pediatric Nephrology, 2003; 18: 843-844.

9) Shimoda T, Ogihara A, Shinohara A, Chiba M: Season comparison of anemia among school-age children in the Aral Sea region, Kazakhstan, Japan. Society of Nutrition and Food Science, 2008; 62: 297. (in Japanese)

10) Chiba M, Shinohara A, Sekine M, Hiraishi S, Inaba Y: Drinking water quality from the aspect of element concentrations. J Radioanalytical and Nuclear Chemistry, 2006; 269: 519-526.

11) Ogihara A, Chiba M, Hashizume M, et al: Simple tests of drinking water samples collected in the east region of the Aral Sea from the aspect of seasonal variation. Japanese Journal of Hygiene, 2003; 58: 158. (in Japanese)

12) Kunii $\mathrm{O}$, Hashizume M, Chiba M, et al: Respiratory symptoms and pulmonary function among school-age children in the Aral Sea region. Archives of Environmental Health, 2003; 58: 676-682.

13) Miyamoto H, Chiba M, Hashizume M, Kunii O: Respiratory dysfunction and environmental conditions in children living near the Aral Sea. Juntendo Medical Journal, 2008; 54: 214-221. (in Japanese) 